\title{
Military Terrain Trafficability Analysis for North-East Nigeria: A GIS and Remote Sensing-Based Approach
}

\author{
${ }^{1}$ Sadiya T.B., ${ }^{1}$ Eta J., ${ }^{1}$ Oladiti I., James GK., ${ }^{1}$ Shaba H.A., ${ }^{1}$ Mamfe V., \\ ${ }^{1}$ Muhammad S.O., Xu M., ${ }^{1}$ Sha J., ${ }^{1}$ Sanusi M. \\ National space research and developent agency, abuja, nigeria.
}

\begin{abstract}
Insurgency in Nigeria is becoming an order of day, especially in the north-east and the Niger-Delta due to the presence of Jamā'at Ahl as-Sunnah lid-Da'wah wa'l-Jihād or Boko-haram (meaning western education is forbidden) and militants such as the Niger Delta avengers (NDA) or Movement for the Emancipation of Niger Delta (MEND) respectively. Although the government is working hard to contain insurgency by sending military troupes to affected areas, there is still a lot to be done especially in the use of spatial terrain analysis for counter terrorism. Thus, this research has utilized the availability of satellite images to extract information of North-east terrain trafficability for strategizing by the military field commander. The analysis involves the use of land use/land cover classified satellite image, floodplain and floodability maps, digital elevation model (DEM), slope, soil information and hillshade images. All the shapefiles were converted into raster, re-scaled to $22 \mathrm{~m}$ and indexed into five classes with the least trafficable areas having index 1 while the fastest trafficable areas were given an index of 5. The result of the conversions were inputted into the weighted overlay model which computes a trafficability suitability ratings represented by NO-GO, SLOW-GO, MODERATE-GO and GO areas according to their ability to allow movement respectively. The result showed $3.66 \%$ and $16.1 \%$ of the study area are NO-GO and SLOW-GO respectively with Local Government Areas (LGAs) at the extreme east (i.e. in and around Lake-chad) having the worst trafficability ratings (NO-GO and $S L O W-G O)$ especially in the rainy season when the marshland/wetland is wet, and the flood-plain of Adamawa state when flooded either due to dam release from Lagdo dam of Cameroon or due to heavy rainfall, Maiduguri is also in this category because of the presence of obstacles such as built-up areas. Meanwhile $45.2 \%$ of the study area is MODERATE-GO due to Aeolian/desert soils while 35.0\% of the study area has a GO rating because it does not hinder movement.
\end{abstract}

\section{Introduction}

Insurgency in Nigeria is becoming persistent, with insurgents taking advantage of some of Nigeria's most inaccessible terrain landscape such as the Lake Chad Basin to move around, bivouac and launch offensive campaigns. These insurgents include Boko Haram (BH) in the North East and more recently the so called Niger Delta Avengers operating in the creeks of the Niger Delta in Southern Nigeria. Since 2009 Nigeria, has had several terrorist attacks which have claimed the lives of more than 20,000 people, and left over 2.5 million people homeless (UN-OCHA, 2016). The Nigerian government through the military and paramilitary forces has been trying to put an end to this National Security threat. However, the regions inhabited by the insurgents are quite remote. The Lake Chad Basin on the Nigerian side is under populated in many areas. For example, Mobbar LGA which was once captured by Boko Haram (BH) has never had a constructed tarred road leading to any of its surrounding LGAs. So also is Marte Local Government, an area heavily infested with BH had a population density of 35 persons $/ \mathrm{km}^{2}$ and a population of 129,370 at the 2006 before the rise of insurgency (National Population Commission, 2006). There were no motor-able roads leading from Dikwa LGA to Marte LGA. The only road linking Dikwa to Marte was built in the 1970s and it had fallen into disuse from potholes and large tracts where the bitumen has disappeared. In many of the local government, during the rainy season, the motorable dirt roads become impassable because the clay content of the saturated soil makes vehicle tyres to lose traction while foot traffic can only move slowly.

Because of the remoteness of these regions, it becomes incumbent on the Nigerian military to use satellite data to identify and track the presence of insurgents. One of the ways of doing this is to determine the level of remoteness of these areas through trafficability analysis so that the military logistics can be more effective.

There have been many analyses performed on a GIS platform to assist counter terrorism operations. For instance, Sadiya et. al (2016) carried out a research on spatial terrain visualization for battlefields in northeastern Nigeria where satellite images, insitu data, previous knowledge (i.e. ground-truth) of the study area and digital elevation model (DEM) were used to analyze the terrain characteristics and determine suitable locations for concealment and/or cover index in the battlefield. 
There are publications on the use of GIS softwares and qualitative spatial reasoning to determine off-road terrain trafficability index in the form of GO, GO-SLOW and NO-GO areas (Donlon and Fobus, 1999; Mersiovsky, 1998; U.S. Army, 1961; Shoop 1993; Slocum, 2003).

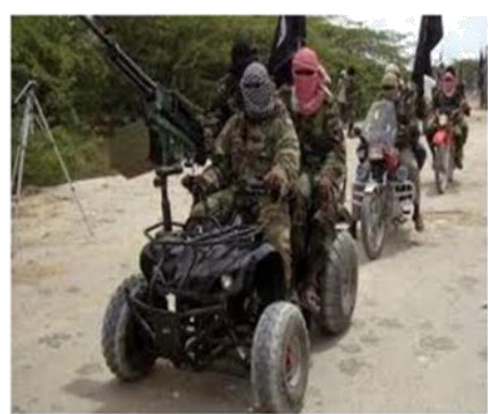

(Source: ICIR, 2015)

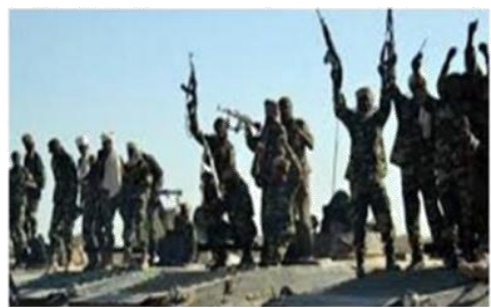

Fig 1. Insurgents using heavy artillery in North-east

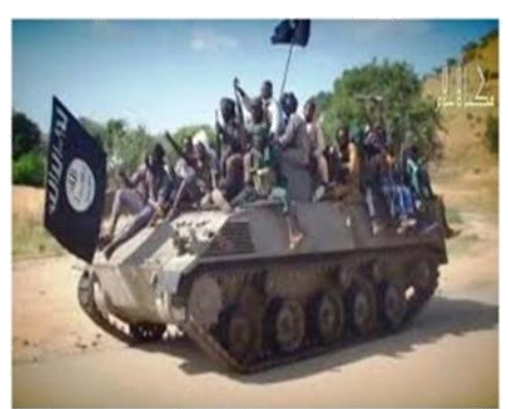

(Source: Starconnect, 2015)

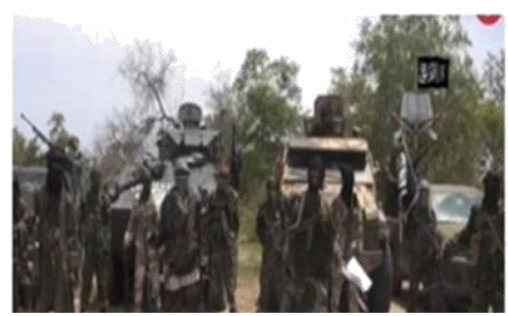

\section{Study Area}

The study area is located in North-Eastern Nigeria consisting of three states namely Adamawa, Borno and Yobe bounded by coordinates of $10^{\circ} 0^{\prime} 0^{\prime \prime} \mathrm{E}$ to $14^{\circ} 0^{\prime} 0^{\prime \prime} \mathrm{E}$ and $6^{\circ} 0^{\prime} 0^{\prime \prime}$ to $14^{\circ} 0^{\prime} 0^{\prime \prime} \mathrm{N}$. it also shares a border with Cameroon, Niger and Chad, its elevation lowest is 130m Above Sea Level (ASL) while the highest is Adamawa Plateau or Vogel Peak bordering Cameroon at 1500m (ASL) (Imaah, 2008 and Sadiya et al., 2016).

Generally the geology of northeastern region consists of three major groups of rocks; Precambrian Basement Complex, Cretaceous Sediments and Tertiary/Quaternary volcanic rocks of the Biu Plateau (Carter et al., 1963). The Basement Complex rocks are grouped into two; the magmatite-gnesis complex and the older granites. The Southern and Eastern part of the area is predominantly hilly and characterized by mountains, plateau, ridges, escarpment and related features, the geology which is underlying by the basement complex (Udo, 1970). The landscape developed on the young sedimentary rock on the Chad formation.

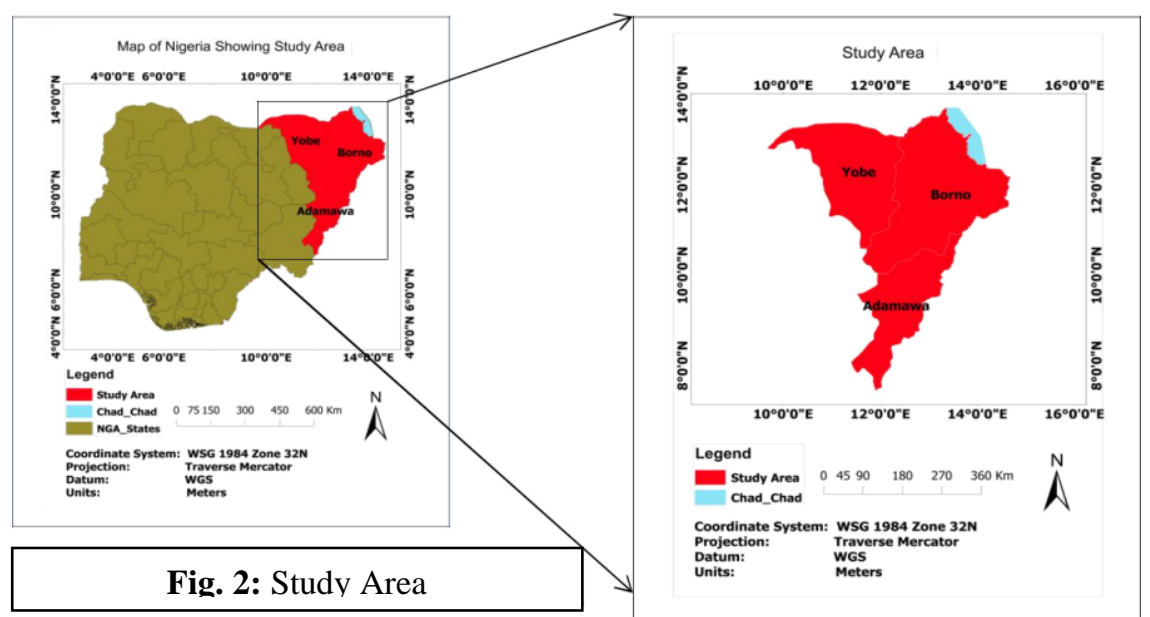

The area features a variety of fluvial and Aeolian like fossil sand dunes, beach ridges, and interdunes ridges depression (Thiemeyer, 1992). Detail vegetation characteristic of this region is explained in Sadiya et. 2016. 


\subsubsection{Data and preprocessing}

\section{Methodology}

NigeriaSat-X data of July, 2011 and July, NigeriaSat-2 scenes of 2014, waterbody, communication line (transportation), and settlement shapefiles were obtained from National Space Research and Development Agency (NASRDA), surface material (soil) data from Ministry of Agriculture was obtained, shuttle Radar Topography Mission (SRTM) 90m were obtained from USGS. All data were projected to UTM Zone 32N while NigeriaSat-X, NigeriaSat-2 images and SRTM. In addition, contours were extracted from SRTM and a digital elevation model (DEM) was created from it and displayed in 3D (Fig 9). Current extent of forest reserves were digitized from NigeriaSat-2 images while NigeriaSat-X scenes were classified using objected-oriented classification method (Fig. 4) (Sadiya et. al, 2016); Floodplain extent data of 2012 were extracted from MODIS image of September, 2012. Soil and flood vector data were converted to raster. All data were resampled to $22 \mathrm{~m}$ respectively and re-classed into five classes numbering 1 to 5 (where 1 represents slowest and 5 represents fastest trafficability locations).

Algorithms were either adapted or developed (see appendix II) and table 1 for criteria of class selection used in developing the trafficability ratings for the North-east. Fig. 3 represents stages taken to arrive at the result.

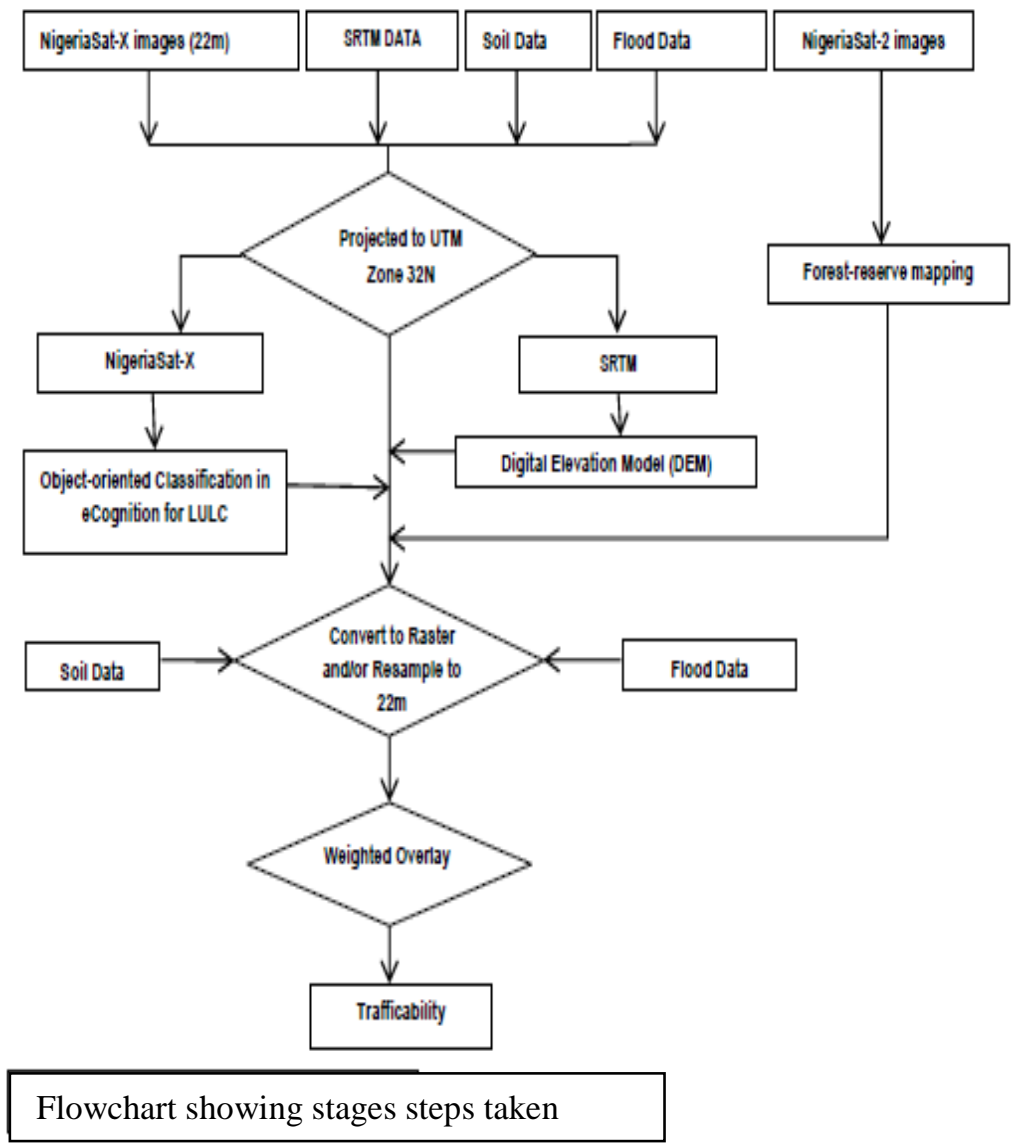

Elevation data obtained from SRTM was reclassified into five classes (Fig. 3c) with 1 representing least trafficable (NO-GO) areas at $1569 \mathrm{~m}$ (ASL) while 5 represent highly trafficable (GO) areas at $315 \mathrm{~m}$ (ASL). Secondly, Flood data was extracted from MODIS scenes produced in 2012 to capture the Lagdo dam break from Cameroon. The dam break in September, 2012 resulted in flooding several states in Nigeria including Borno and Adamawa state, thus, the floodplain was digitized and reclassed in to 1-to-5 classes representing lowest to highest flood risk areas respectively (Fig. 6c). Thirdly, slope was calculated from DEM (Fig. 5) to determine locations that are steep which are represented in red. This is because, the steeper the elevation the slower the trafficability. In addition, land use and land covers (Fig. 6b) classes were also merged into five classes (Table 1) according to their ability to allow or hinder movement. However, low pressure tires such as All-Terrain-Vehicle can navigate semi-arid soil, rocky, muddy and root covered terrain but could not traverse wooded trails, dirt road, hills and creeks (MMWR, 2008 and RM-TEREX, 2012). Tracked vehicle can also traverse the semi-arid regions with relative ease but not hills and mountains which require specially trained mountaineers (FM 7-20, 
1978 and FM 90-6, 2000). The semi-arid soil of Sahel savanna could also present obstacle to movement in the form of sand dunes which can reach a height of 1000ft and 10-15miles long (FM 90-3, 1993); locations with high elevations were also added to this category considering they slow down wheeled, tracked and foot traffic; so also are forest reserves (FM 7-20, 1978). Built-up areas are considered as an obstacle even as rubble (FM 720, 1978). It should be noted that this analysis and indexes were done based on off-road terrain and obstacle that appear on the $22 \mathrm{~m}$ satellite images. Agriculture does not have much effect on trafficability in the semi-arid regions of the Sahel except for the water canals of the Hadejia-Jamaare and the cultivated lands of the Sudan, Guinea and Derived savanna during the rainy season due to the extent of crop coverage (FM 90-3, 1993 and Sadiya et al., 2016). In addition, destroying agriculture to make way for the fighters could have a devastating effect on the economy and livelihood of the residents since most of the population depends on farming for sustenance, therefore, in order to reduce the number of young men joining insurgency, agricultural lands should not be destroyed unnecessarily (FM 90-3, 1993 and Sadiya et al, 2016).

\begin{tabular}{|c|c|c|}
\hline No. of & Merged Classes & Index \\
\hline \multicolumn{3}{|l|}{ classes } \\
\hline 1. & $\begin{array}{l}\text { Built-up Areas + Waterbodies }(\text { depth }>=5 \mathrm{ft})+\text { Rock-outcrop } \\
+ \text { Wetlands + Elevation }(>=900 \mathrm{~m})+\text { Highest Risk/vulnerable Flood } \\
\text { area }\end{array}$ & 1 \\
\hline 2. & $\begin{array}{l}\text { Dense vegetation }+ \text { Forest reserves (tree diameter }>=8 \mathrm{~m} \text { and tree } \\
\text { spacing }<=15 \mathrm{~m})+ \text { Baresurface (desert/Aeolian soils) }+ \text { High } \\
\text { risk/vulnerable flood area }+ \text { Elevations }(600-900 \mathrm{~m})+\text { Sand dunes } \\
(12-30 \mathrm{~m} \text { high, } 275-365 \mathrm{~m} \text { wide and } 800 \mathrm{~m} \text { to } 12 \mathrm{~km} \text { long) }\end{array}$ & 2 \\
\hline 3 & $\begin{array}{l}\text { Moderately dense vegetation }+ \text { Moderate flood risk/vulnerable } \\
\text { area }+ \text { Elevation }(400-600 \mathrm{~m})+\text { Baresurface (Undifferentiated } \\
\text { Basement Complex })\end{array}$ & 3 \\
\hline 4 & $\begin{array}{l}\text { Cultivated lands + Low Flood risk/vulnerable areas }+ \\
\text { Elevation }(300-400 \mathrm{~m})+\text { Baresurface(Savanna or Alluvium } \\
\text { over granitic soils) }\end{array}$ & 4 \\
\hline 5 & $\begin{array}{l}\text { Sparse Vegetation + No-risk/vulnerable flood area }+ \\
\text { Elevation }(<=300)+\text { Baresurface(Sandstone, Mustone and } \\
\text { Shales soils })\end{array}$ & 5 \\
\hline
\end{tabular}

Table1: Merged classified classes for trafficability analysis index.

Weather in this region is neither friendly to the foe nor the friendly forces and visibility in the study area can change from several kilometers to few feet within a short period of time due to sand storm that plagued the area from February-to-October and December-to-June (Rayar, 1996; Middleton, 1985; Bankole et. al, 1994 \& CBDA, 1986). This can hinder movement for either side except the side that has a night vision glasses or a good knowledge of the terrain (Lane, 1986; FM 90-3; 1993; Sadiya et al, 2016, Rayar, 1996; Middleton, 1985; Bankole et. al, 1994 and CBDA, 1986).

The five layers i.e. DEM, land use land cover, soil, hillshade and flood vulnerability data were all inserted into the weighted overlay model. The Weighted Overlay tool allows the calculation of a multiplecriteria analysis between several raster layers (ArcGIS 10.1, 2012). All overlay raster layers are weighted equally (in this case 1 to 5). An Overlay class is used to define the table. The WOTable object is used to specify the criteria raster and their respective properties. The form of the object is: in_weighted_overlay_table: WOTable ([[inRaster, influence, field, remap],...], [from, to, by])

Output: Suitability raster.

Out_WeightedOverlay $=$ WeightedOverlay(myWOTable $)$ (Adapted from ArcGIS 10.2).

The result is affected if a layer is missing data or an important layer in the model. For instance, missing a soil layer will greatly affect the final result by reducing the accuracy since soil layer contains locations that are mashy/wetland which are important in delineating trafficability.

In this model, all overlays are weighted equally and missing data are represented in the result as NO

DATA instead of giving any value that might affect the accuracy. 


\section{Result And Discussion}
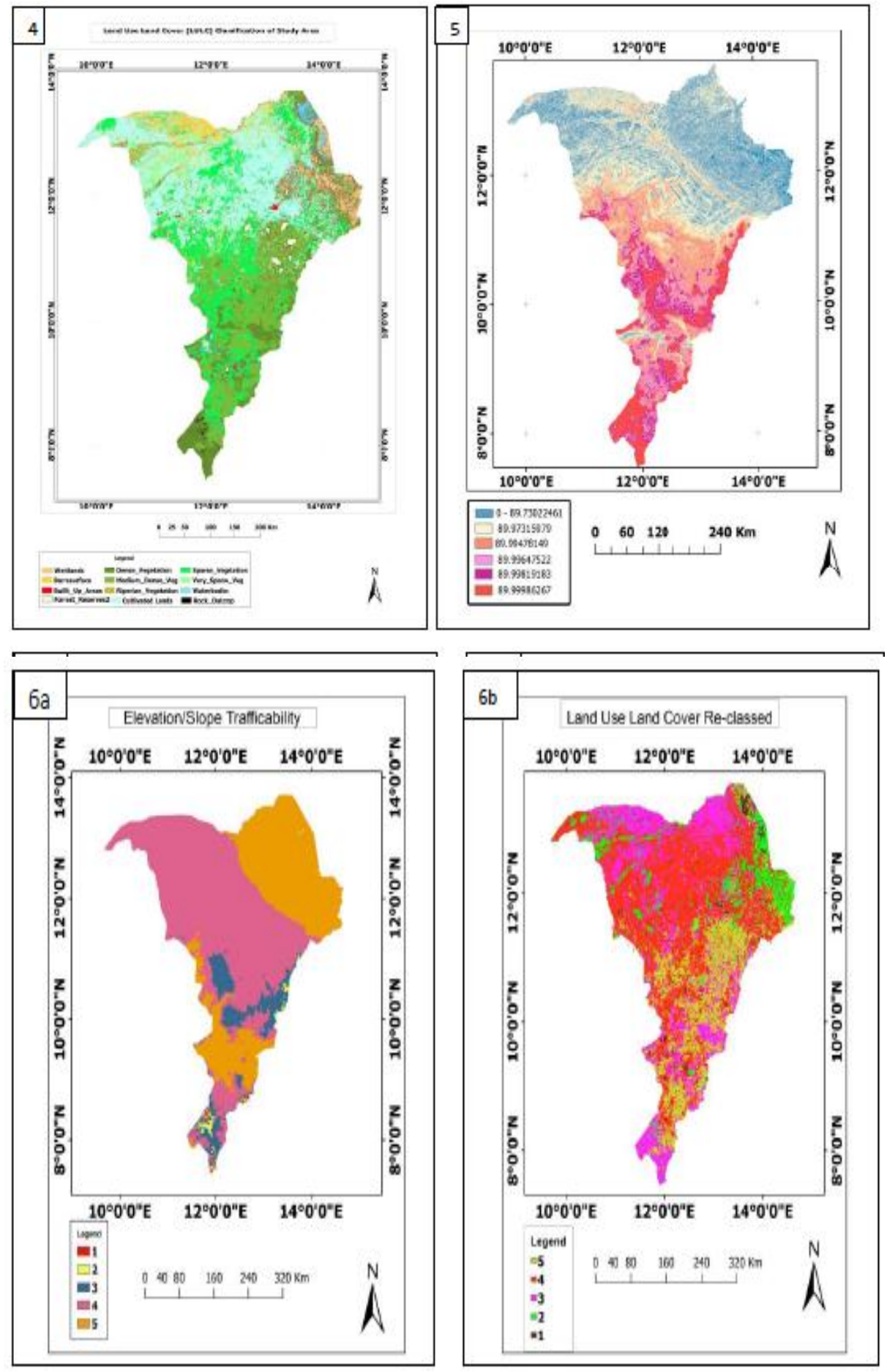


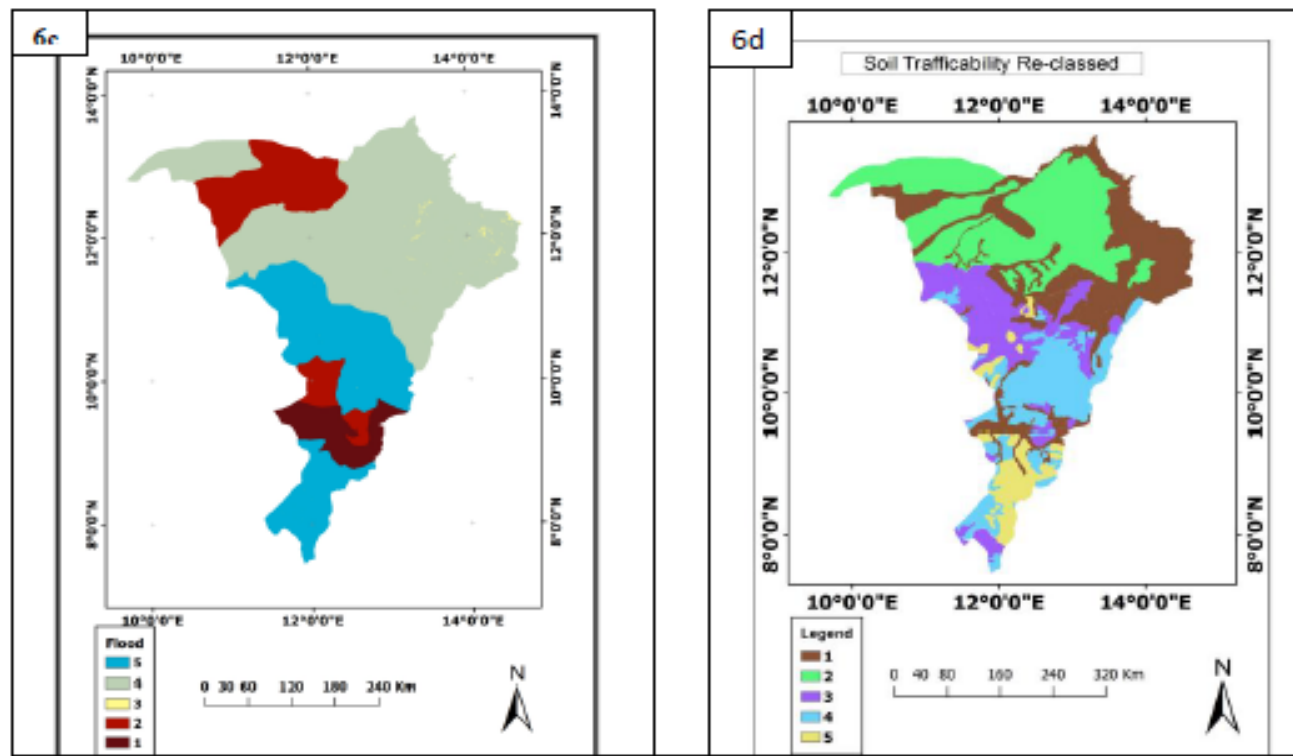

Fig 6a-6d: (6a) DEM reclassed; 6b) LULC Reclassed; 6c) Flood Risk reclassed; 6d) Soil Reclassed
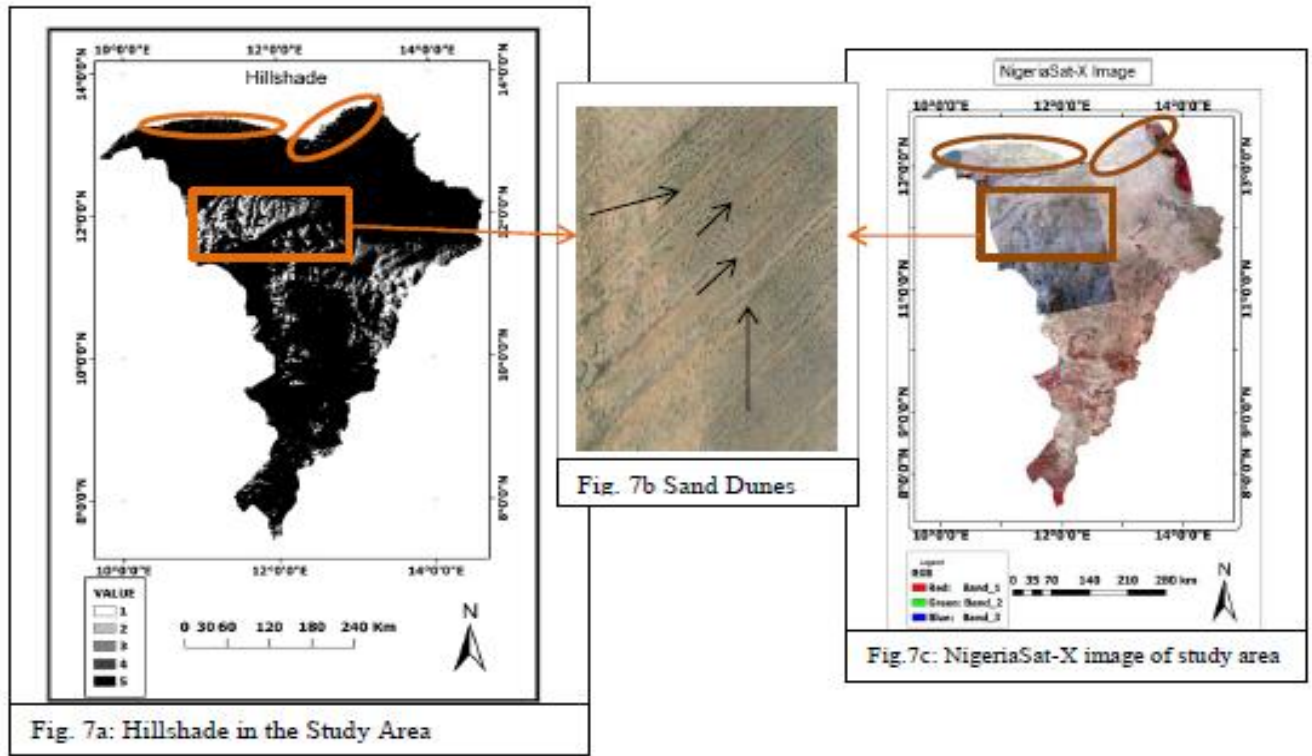

Depending on their sizes and soil texture, sand dunes can hinder or slow trafficability of wheeled or foot soldiers. Fig. $7 \mathrm{a}$ and $7 \mathrm{~b}$ shows locations of some sand dunes which are created due to winds that converge from two directions namely the northeasterly Harmattan winds that originate from the Sahara desert and the southwest monsoon flow that emanates from the Atlantic (Nichols, 2012 and DesertUSA, 2016). The dunes prevalent in the NigeriaSat-X images are Linear or slightly sinuous-shaped trending Northeast to Southwest, found in Hadejia-Jamaare and Lake-chad areas as indicated in the rectangular orange box in Fig.7a and 7b; they are $12-30 \mathrm{~m}$ high and $275-365 \mathrm{~m}$ wide and as long as $800 \mathrm{~m}$ to $12 \mathrm{~km}$ long (Iloeje, 2001 and DesertUSA, 2016) while the dome-shaped dunes are found north of the Sahel region as indicated by the orange cycles in Fig. 7a and $7 \mathrm{~b}$.

From Fig.7a, hillshade values 1, 2 and 3 (i.e. bright locations such as Gujba, Gwoza, madagali, dambuwa, Tarmuwa, Nangere, Jakusko, Mubi North, Mubi South, Bama, Michika, Ganye, Tunga etc.) indicate presence of high elevations from either hills/mountains or dunes (called key terrain) while values 4 and 5 are low elevation areas that can be seen from the top of 1, 2 and 3 respectively with 1 having the highest elevation. Nonetheless, the higher the elevation the steeper and the more difficult the climb (i.e. difficult trafficability) as shown by the slope values in Fig. 5. All terrain analyzed maps were saved in a database for future use in different scenarios. 
Given the thematic layers above, this terrain visualization is design to aid an army terrain analyst or a rescue worker to produce several terrain intelligence maps such as digital elevation model (Fig. 9) depicting a near-real-life image of the study area showing locations of rivers, dams, lines of communication (transportation), forest-reserves and hills/mountains.

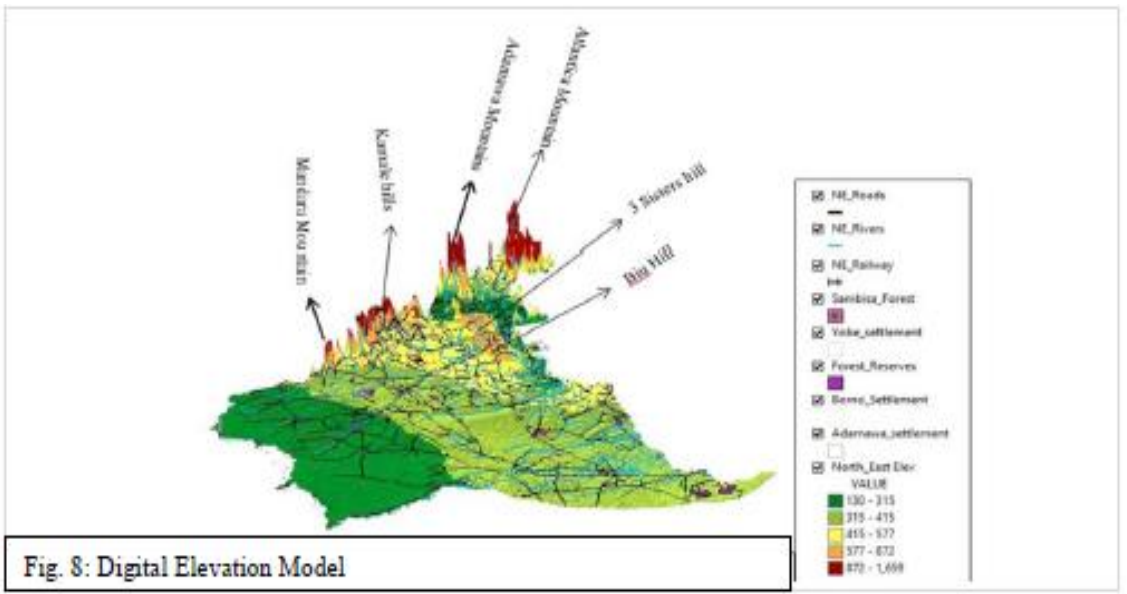

The output of the weighted overlay is shown in Fig.12b where local government areas with their trafficability ratings and percentage coverage (Fig. 11) were mapped. NO-GO and SLOW-GO represent no trafficability covering $3.66 \%$ and slowest trafficability covering $16.1 \%$ of the study area respectively. The none trafficable areas (dark red) are mostly in the extreme east covering some part of Manguno, Mafa, Nganzai, Gambarun-Ngala, Kukawa, Marte, Dikwa, Kala-Balge, Bama, Kaga, Gwoza, Damaturu, Tarmuwa, Fune, Yola North, Yola south, Demsa, Toungo, Bade, Jakusko. SLOW-GO (light red) locations are extremely hard to traverse in the rainy season when the marshlands are wet and sticky (Fig. 9a and 9b) and the waterbodies full (i.e. June to September) or when Cameroon release water from Lagdo dam between August/September. In addition SLOW-GO also includes hills with an elevation of at least $600 \mathrm{~m}$ (Fig. 6c) in high.
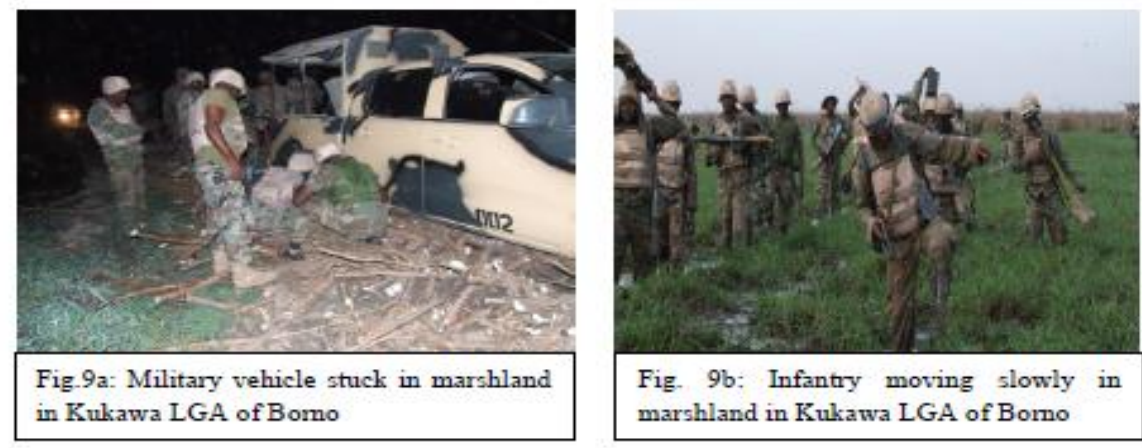

However, reverse is the case during the dry season when the ground is dry; it becomes hard and cracked as shown in fig. 10. This makes trafficability of infantry and vehicle easy.

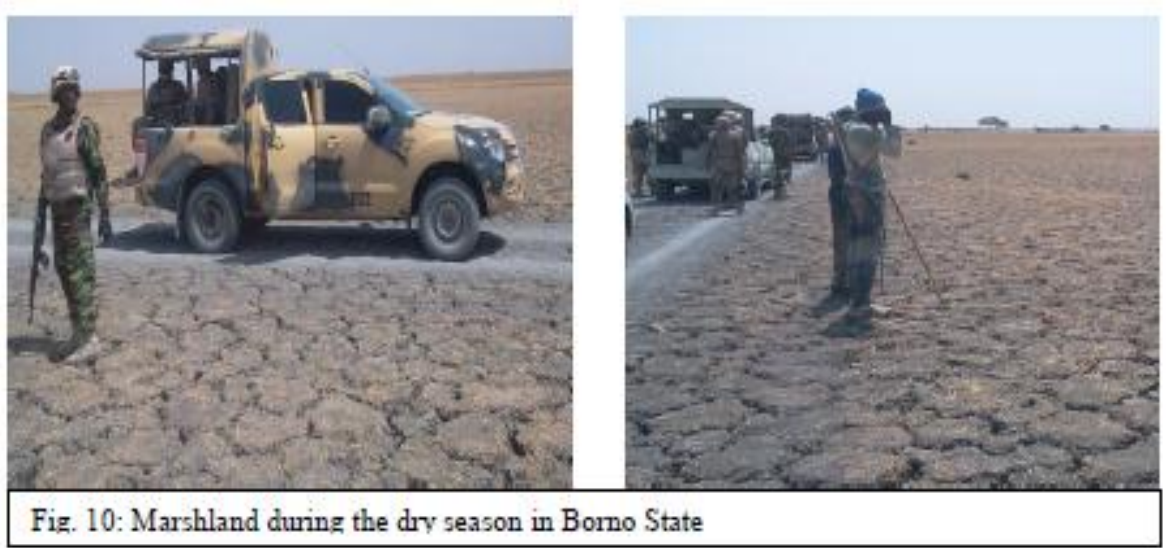


In addition the Sahel savanna soil region experience only three months rain and is represented by SLOW-GO covering $45.2 \%$ of the study area (Fig. 12a) meaning it is moderately trafficable since it can be traversed with low pressure tired vehicle/armored tank/motor cycles and by foot. Meanwhile, GO areas in green colours are locations with no problem of trafficability and it covers $35.0 \%$ of the study area. Fig.12b shows some selected towns in the NO-GO and SLOW-GO areas.

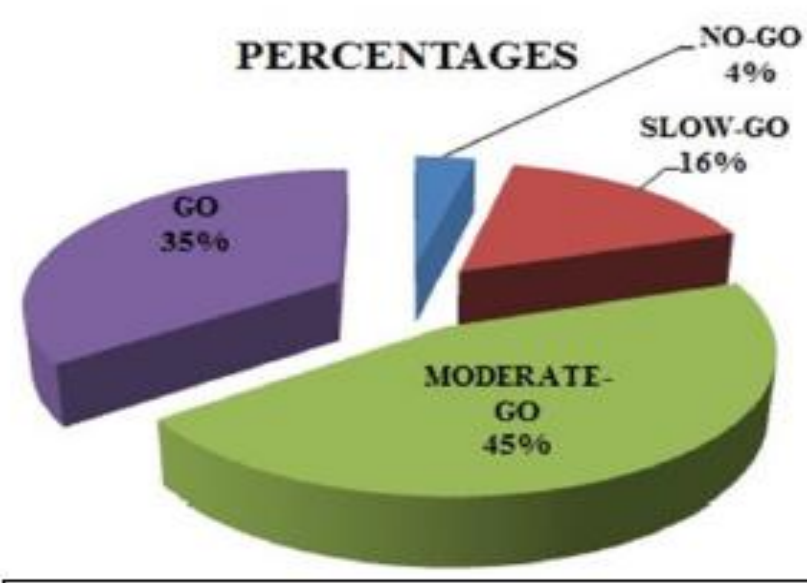

Fig. 11: Percentage Coverage for Trafficability Classes

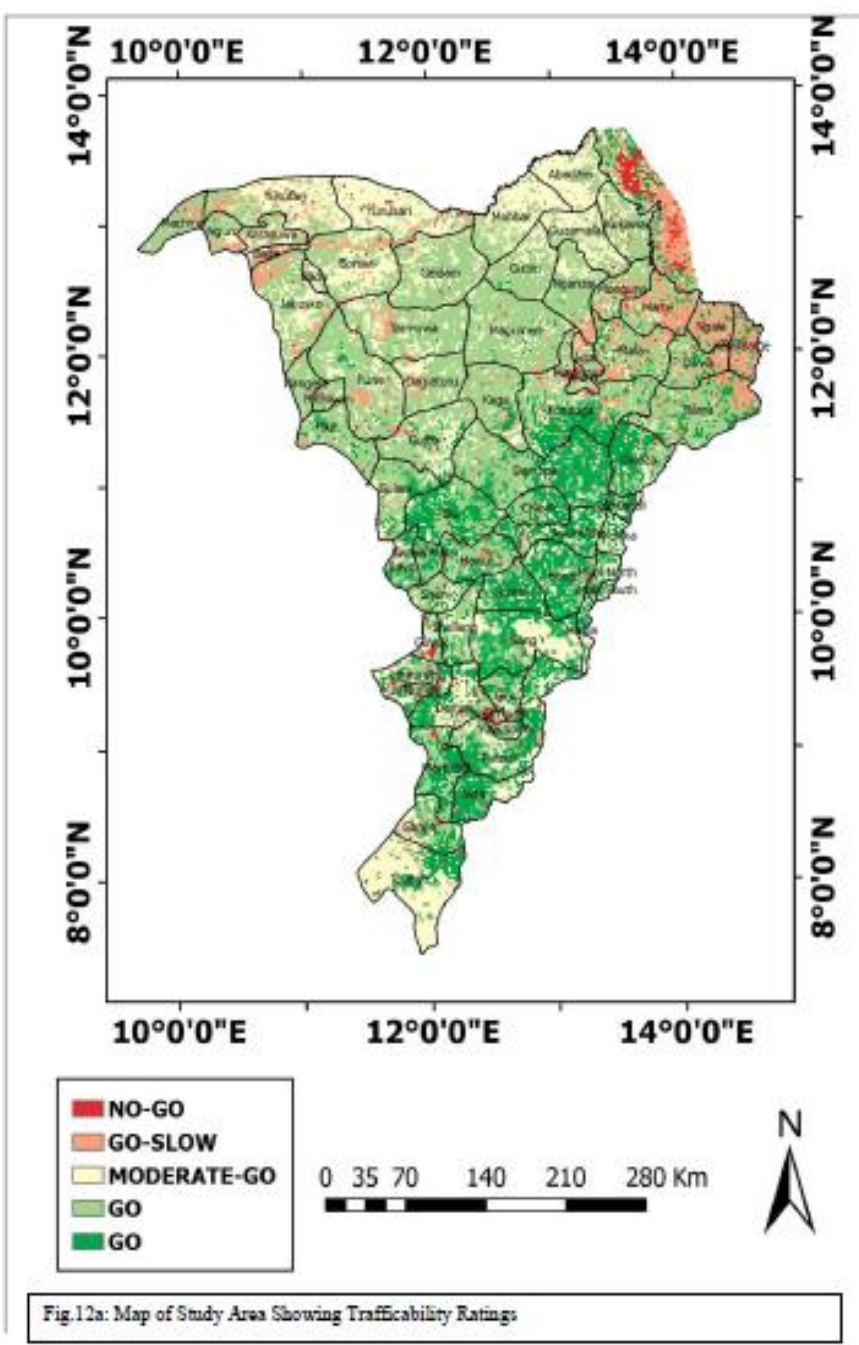




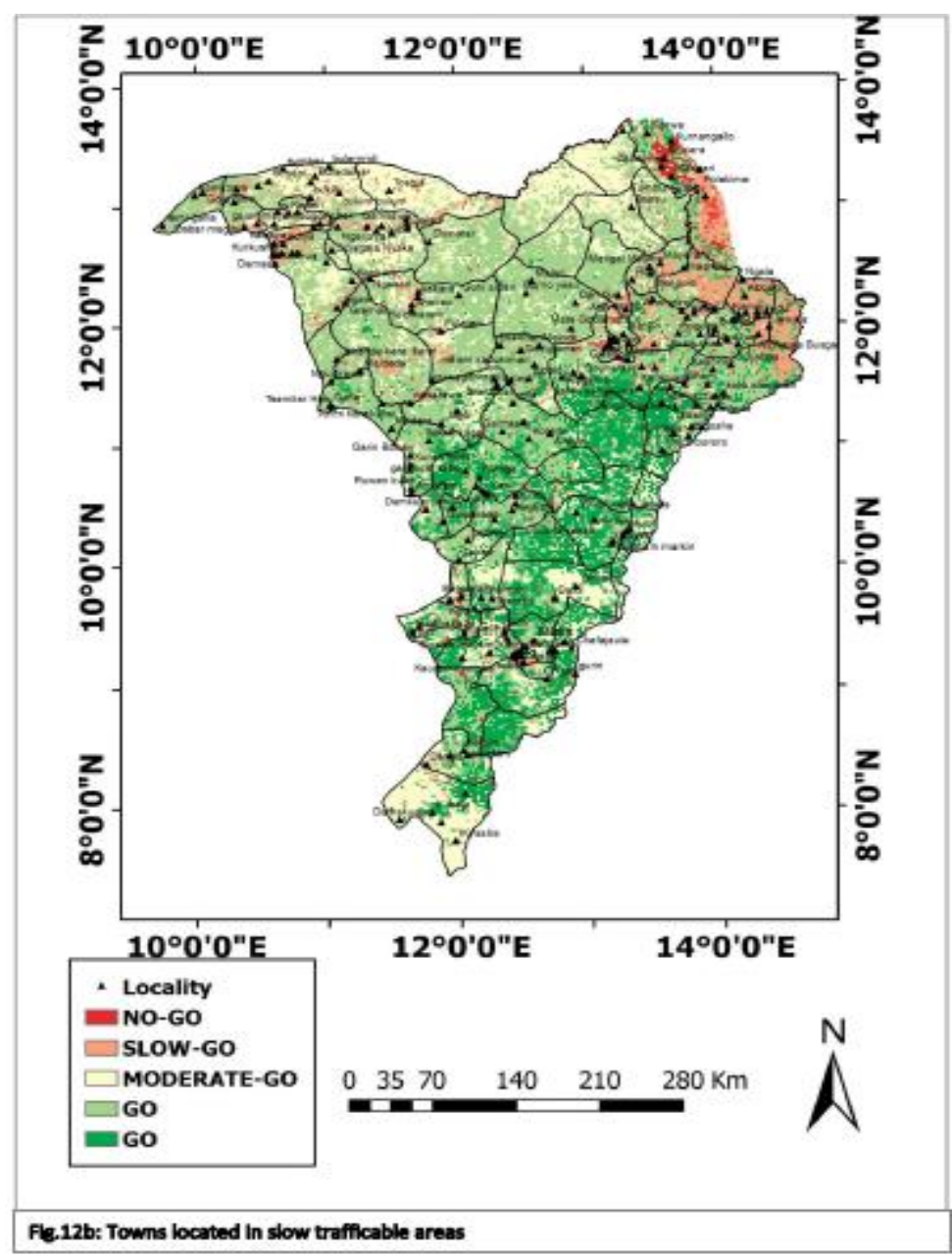

\section{Conclusion}

This research has proven that information about inaccessible terrain can be obtained from satellite/aerial images using GIS and remote sensing with relatively high accuracy. From the result of this research, a field commander can strategies on future operations by knowing which terrain can be accessed offroad without encountering problem and which terrain are not going to be easily accessible if at all before going into the field. In essence, the situation in Fig. 9a and 9b could have been avoided if the military, rescue workers and/or Civilian Joint Tax Force (JTF) has such trafficability suitability maps in their possession before going into the field.

\section{Recommendation}

Gathered from videos, pictures and local interviews reveal that the Boko Haram sect have in their possession heavy duty vehicles and artillery (Fig. 1), which means that such vehicles will have to travel on very particular soil with relatively low elevation to get to their various destinations for their operations. So it will be to the advantage of the Nigerian Armed Forces to know areas with such terrain characteristics that will be suitable for the insurgents to travel on.

\section{References}

[1]. Slocum, K.R., Surdu, J.R., Sullivan, J., Rudak, M., Colvin, N., and Gates, C. (2003) Trafficability Analysis Engine; the Journal of Defense and Software Engineering pp. $28-30$.

[2].

[3]. USGS (2016) http://landsat.usgs.gov/ 3. ArcGIS (2012). http://www.esri.com, 4. http://www.eng.zzgt.ru. RM-TEREX vehicle. 2012. Accessed: 14/04/2016

[4]. Cibulova, K. and Sobotkova, S. (2006) Different Ways of Judging Trafficability, Advances in MT pp.77 - 88

[5]. "http://www.nytimes.com/aponline/2015/11/17/world/africa/ap-af-boko-haram.html?_r=0". New York Times. ASSOCIATED PRESS. 18 November 2015. Retrieved 18 November 2015

[6]. http://www.cdc.gov/mmwr/preview/mmwrhtml/mm5712a2.htm. MMWR. All-Terrain Vehicle Facilities- West Virginia. 2008. Accessed: 14/04/2016.

[7]. https://www.enca.com/africa/boko-haram-death-toll-escalates. AGENCE FRANCE-PRESSE (AFP). 01 October 2015. Accessed 04 February 2016. 
[8]. Http://Icirnigeria.Org/Boko-Haram-Insurgents-Wreak-Havoc-On-Army-Chiefs-Village/.InternationalcenterforInvestigative Reporting. 22 July 2015. Accessed 20 November 2015

[9]. http://starconnectmedia.com/2015/04/25/boko-haram-retakes-nigerias-border-towns/. STARCONNECT MEDIA. 25 April 2015. Accessed 18 November 2015. 11. DesertUSA (2016). The Sahara Desert: Landscape, Water and Climate Information, online: http://www.desertusa.com/du_sahara.html, accessed: 21/05/16

[10]. https://books.google.com.ng/books?id=A55xMlQCzkMC\&printsec=frontcover\#v=onepage \&q\&f=false. TheInfantryBattallion. Headquaters Department of the Army. 1978. Washington DC.

[11]. http://www.sprectre.com.ng/2015/07/boko-haram-kills-25-in-borno.html. Accessed 10 January 2016

[12]. http://www.blacknaija.com/new-update/chadian-children-were-rescued-from-boko-haram Accessed 10 January 2016

[13]. CPT J. J. Donlon \& K. D. Forbus . Using a Geographic Information System for Qualitative Spatial Reasoning about Trafficability. Proceedings of QR99, Loch Awe, Scotland, June, 1999.

[14]. ArcGIS $10.2 \mathrm{Help}()$.

[15]. NASA (2012). Flood in Nigeria. Online: http://earthobservatory.nasa.gov/IOTD/view.php?id=79149, accessed: 12/05/16

[16]. eCognition Developer User Guide (2014). Trimble Germany GmbH, Arnulfstrasse 126,80636 Munich, Germany. Field Manual 3 97.6 (2000). Headquarters Department of the Army Washington, DC eoPortal Directory (2015). NigeriaSat-X. available: https://directory.eoportal.org/web/eoportal/satellite-missions/n/nigeriasat-x, accessed: 23/10/2015.

[17]. Field Manual 90-6 (2000). Mountain operations. Online: https://fas.org/irp/doddir/army/fm3-97-6.pdf, accessed: 3/6/2015

[18]. Rayar, A. J. (1996). Desertification and Soil Degradation in Arid and Semi Arid regions in Nigeria. University of Maiduguri inaugural lecture series No. 55 University of Maiduguri Press, Pp 1-9.

[19]. Middleton, N. J. (1985). Effect of drought on dust production in the Sahel, Letters to the Nature, Vol. 316, 1st August, 1985. Weekly Bulletin, School of Geography, University of Oxford, United Kingdom, pp 9-12.

[20]. Ijiofor, C. (2015). Naij.com, 'Boko Haram Militants Set Military Base On Fire In Adamawa', accessed: 3rd/12/2015, available: https://www.naij.com/652411-boko-haram-militants-set-military-base-fire-stole-weapons-adamawa.html

[21]. Sobulo, R.A. (1985). Soil fertility and management in Nigeria. In: Saka Nuru and R.G. Ryan eds. Proceedings of Nigeria-Australia Seminar on Collaborative Agricultural Research, Shika, Nigeria, $14-15$ November, 1983. ACIAR proceedings Series, No. 4. pp 33-37. 29. Nicholson, S.E. (2012). The West African Sahel: A Review of Recent Studies on the Rainfall Regime and Its Interannual Variability. Online: http://dx.doi.org/10.1155/2013/453521, accessed: 20/05/16

[22]. Thimeyer, H. (1992). On the age of Bama Ridge-A new record from Konduga area, Norno state, NE-Nigeria. Z. geomorph. N.F. 36, 113-118.

[23]. Udo, R.K. (1970). Geographical regions of Nigeria, Ibadan, Heinemann pp. 198-201.

[24]. Carter J.D., Barber D.F. \& Tait E.A. (1963). The geology of parts of Adamawa, Bauchi and Borno provinces in North-eastern Nigeria. Geol. Surv. Nigeria, Bull. No. 30. 33. http://www.population.gov.ng/index.php/censuses, 34. Mersiovsky, E. (1998). Soil Interpretations for Military Manoeuvres, www.dtic.mil/dtic/tr/fulltext/u2/265743.pdf, accessed: 24-06-2016 35. U.S. Army Technical Memorandum No. 3-240 (1961) Trafficability of Soil: Soil Classification, online: www.nrcs.usda.gov/Internet/FSE_DOCUMENTS/nrcs142p2_052024.pdf, accessed: 24th-06-16. 36. Shoop S.A. (1993). Terrain Characterization for Trafficability, online: www.dtic.mil/dtic/tr/fulltext/u2/a269925.pdf, accessed: 24-06-2016. 37. National Population Commission (2006). http://www.population.gov.ng/index.php/publications/138-national-and-state-population-andhousing-tables-2006-census-priority-tables-vol-1 11.

\footnotetext{
Appendix I

Jakusko LGA: Tasgan Gabas, Tagan Zawai, Damasa. Gashua, Adiya, Guzambana, kajuwa.

Bade LGA: Kabaya, Azam kura, gojagaja nyake.

Bama LGA: Bulabulin, kote mamman, Gwanje, Ledede, Sham, Gooni kurmi, Bula gajiye,

Kashimri, Gulumba.

Bayo LGA: Gulankasa, Damkum jamri. in Biu: Yawi, Hizhi gwaram, Mirnga, Garabula sabo.

Borsari: Ngarbiya, S/gari Guba, Julliri, Dalari, Gamsawa, Kankare, Rawankunu.

Damboa LGA: Alhajiri, Korede, Michiama A, Gola, Galmasku.

Demsa LGA: Jambutu, Bekaji, Lainde, Koh, Kwayne, Dubire, Kaurame wappa.

Dikwa LGA: Bubdo, Muduwa, Mangari, Ngubgori, Abbari Mohd, Magirta, Amharas Busge, Wundula, Gajibo, Segnabava, Masarmari, Mudu, Tubun yashi.

Fika LGA: Maidede, Gana, Tsamitar Hutu, Turmi karaikarai, Madara.

Forore LGA: Bakin Kwata, Nrurore, Gurin, Chigari, Gremari,

Ganye LGA: Patolom, Sitin, Dango

Gujba LGA: Kajidiri, Kaidiri, Buni-yadi, Nasarawa, Jugu, Gotala kawarma, Gwaggonmari.

Gulani LGA: Kuran mota, garin Maikomo, wakilin kaga, Ruwan kuka, Amanda

Guyuk LGA: Kola tudu, Bagwala

Gwoza LGA: Gonza, Ngoshe, Jango Ngabura, Ashigashiya, Kundesana, Njibiya, Fadagwe Christain, Wuro

Bororo

Hawal LGA: Kirmi, Dabiro, Kwajafa, Lokoja Bula

Hong LGA: Lubum, Mucham Markin, Mubula Kasaa, Wuro Wawa Jeg

Jere LGA: Fanamuri, Kisheri, Matari

Kaga LGA: Tobolo, Settimari, Malam Kabukimar, Goduromari, Shandari, Mainok

Konduga LGA: Malam kyariri, alagarno, Bounaram, Kafaruwa, Wanzamari, Kaleri sabsauwa

Kukwa LGA: Mangari, Polekime, Shuwara, Zabarmari, Kanwa, Kurnangallo,

Mafa LGA: Azunguro, Bale, Anaduwa, Mogone, Maska Jibirin

Maiduguri LGA: Old Maiduguri, Gwange, Mairi, Modu Kumari, Federal Low Cost, Alau Lawanti.
} 
Marte LGA: Kaje Futeme, Mashilla

Monguno LGA: Marayam, Rilla, Mubi, Vimtim

Gamburun-Ngala LGA: Maleri, Koma, Antiliske, Abbari, Ngal

Nganzai LGA: Matagodurmari, Jugudanna, Dabar Magini,

Yola North LGA: Dogirei, Wuro Hausa, Chafajaule,

Yusufari LGA: Garin Dan Kaka, Buladawa, Bukarti Mainawa, Bulum Bulum, Bukku, Bulamridi, Sumbur etc.

\section{Appendix II \\ Algorithm using the geometric processing library of ARC/INFO were either developed or adapted in the appendix:}

(defRelation untrafficable

surface (?T ?V) := (or (too-

steep ?T ?V)

(floodable ?T ?V) (too-

vegetated ?T ?V)

(weak-soil ?T)

(weather-denied ?P ?M)

(obstructed-surface ?T)

(dvalue (obstacle-category ?t) W))).

.(adapted from Donlon and Forbus, 1999.

However, although some part of the north-east is characterised by sand-storm; weather-denied condition is assumed false in this model because the storm does not have a specific time of occurring. Nonetheless, expanding the algorithm further:

(defRelation too-

vegetated $(? \mathrm{~T} ? \mathrm{~V}):=$

(and (vegetated ?T)

(and $(<$ (forest-reserve

?T) (min-turning-radius

?V))

(> (Dense-vegetation ?T)

(thickness ?V)))))

The above algorithm determines how trafficable forest-reserves and dense-vegetation are, depending on the thickness of the vegetation.

(defmodelfragment

movement-rate-vegetation-effects

:participants ((M :type movement-episode)

(P :type path))

:conditions ((possible-trajectory-of M P))

:consequences

((qprop+ (movement-rate M P) (SD P)) where SD = Stem Distance

(qprop- (movement-rate M P) (SW P)))) $\quad$ SW = Stem Width

Movement speeds of vehicles are high when travelling through the sparse and moderately dense

vegetation as shown in the NigeriaSat-X classfication.

During sand storm, an event that happen in the Sahel and Sudan savanna around October to February and December to June; visibility can be zero (Rayar, 1996; Middleton, 1985; Bankole et. al, 1994 \& CBDA, 1986, FM 90-3, 1993 \& ), so also is during heavy rain, visibility can be very low, both condition can affect trafficability immensely:

(defmodelfragment

Trafficability-weather-

conditions :participants $((\mathrm{M}$

:type movement-episode)

(P :type path))

:conditions ((possible-

trajectory-of M P))

:consequences

((qprop

(movement-rate $\mathrm{M}$

P) (visibility P)) 


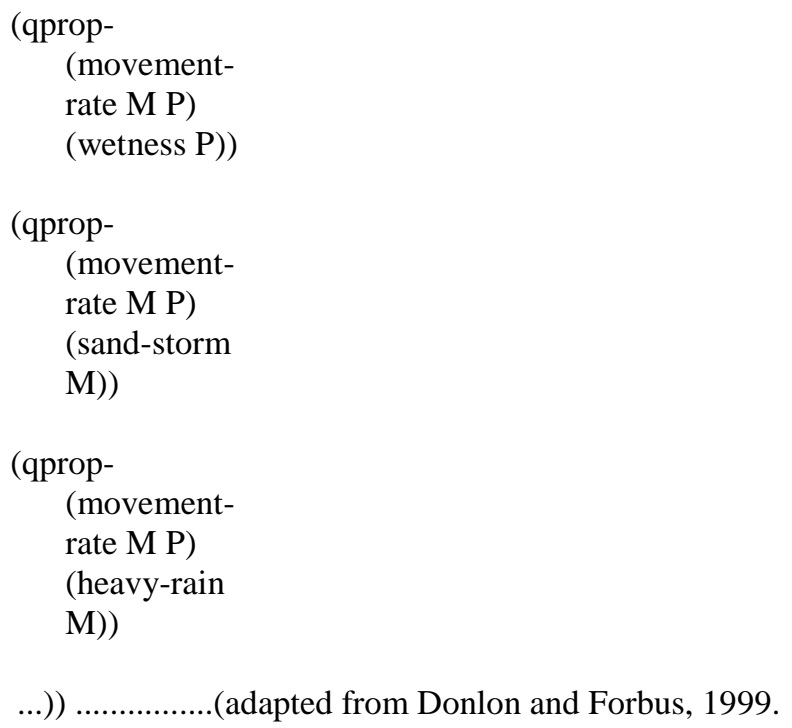

For a severely restricted terrain where elevation is at least $600 \mathrm{~m}$, weak soil (i.e. arid and marshland), forest-reserves and dense-vegetation; vehicle movement is severely restricted or completely in-accessible is represented by the algorithm below:

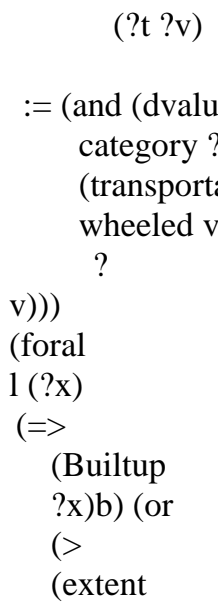

(building, masonry))

(forall $(? \mathrm{t})$

(=> (and (landform ?t)

(or (>= (elevation ?t) 900m)

))

(dvalue (obstacle-category ?t) SR)))

(forall (?t)

(=> (and (waterbody ?t) 


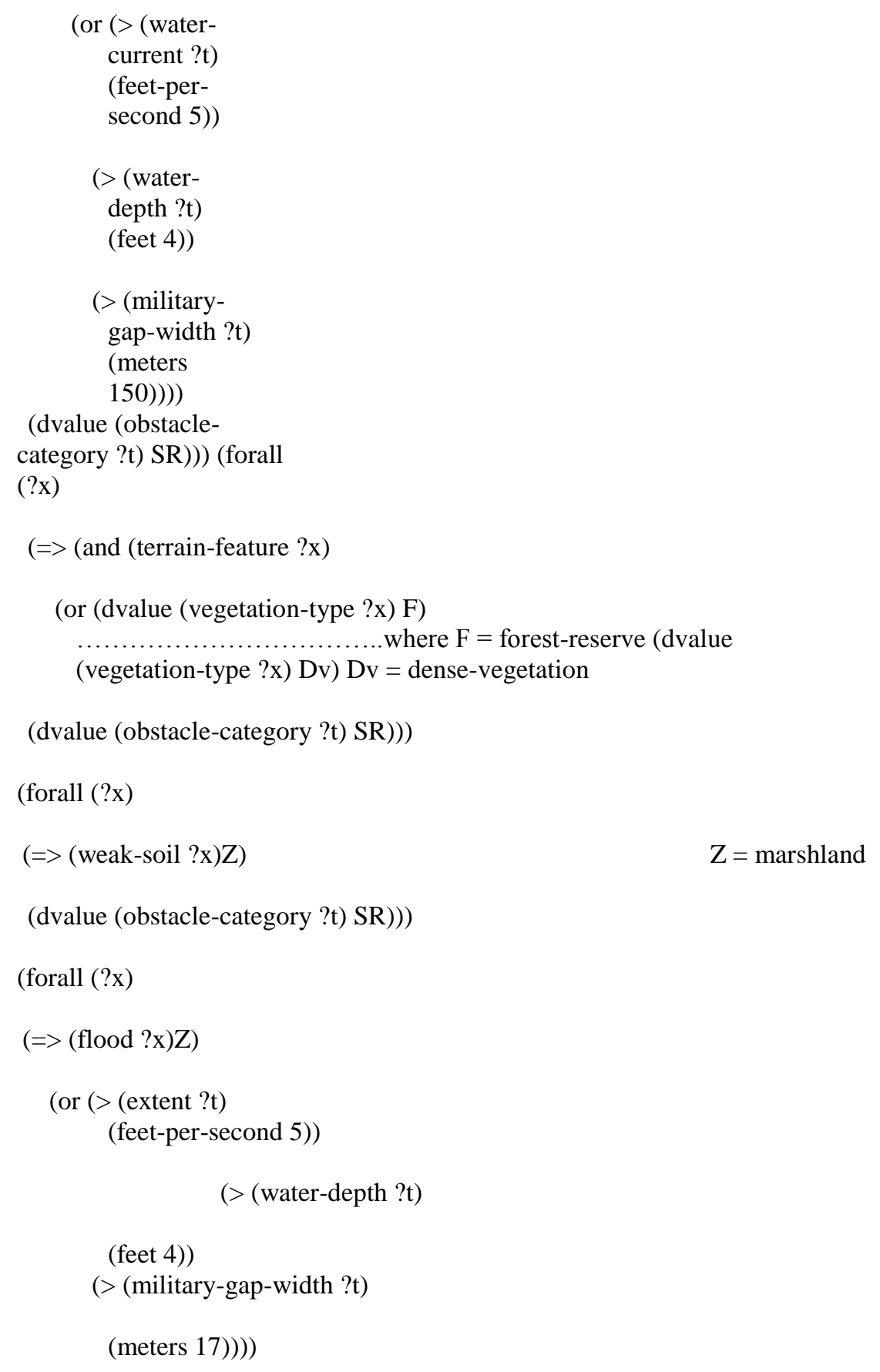

(dvalue (obstacle-category ?t) SR))) 